\title{
Structured Clinical Teaching Initiatives: A Preparation for First Year Nursing Students as First Timer in the Clinical Placement
}

Wong Pei Yen ${ }^{1^{*}}$, Noor Rehan Z Abidin ${ }^{2}$, Noor Hisham Mansor ${ }^{2}$, Annamma K $^{1}$ and Hamidah Hassan ${ }^{1}$

${ }^{1}$ KPJ Healthcare University College, Malaysia

${ }^{2}$ KPJ Tawakkal Specialist Hospital, Malaysia

"Corresponding author: Wong Pei Yen, KPJ Healthcare University College. Lot PT 17010, Persiaran Seriemas, Kota Seriemas, 71800 Nilia, Negeri Sembilan Darul Khusus, Malaysia, Tel: 606-792692; E-mail: info@kpjuc.edu.my

Received date: November 09, 2017; Accepted date: November 23, 2017; Published date: December 1, 2017

Copyright: (c) 2017 Yen WP, et al. This is an open-access article distributed under the terms of the Creative Commons Attribution License, which permits unrestricted use, distribution, and reproduction in any medium, provided the original author and source are credited

\begin{abstract}
Clinical learning is a fundamental element in nursing curricula from the sourcing of appropriate experiences for students to national board registration requirements and workforce requirements. For nursing students, the first year of their first semester experience of being in the clinical area is daunting and the exposure to caring for life is overbearing for them. Students are very scared of making mistakes and harming the patients. Good clinical nursing environment is not only plays an important role in the development of the students' competency but also their confidence, organizational skills, and practical preparedness. The purpose of this study was to prepare the first year nursing students the confidence level through structured clinical teaching initiatives, called CNI. This is a Quasi Experimental one group pre and post-test design. Samples had been selected from 30 students of the Diploma of Nursing program in First Year and First Semester. CNI emphasized the structured clinical teaching and supervision for three consecutive semesters from Semester 1 to Semester 3. Results revealed that, students exhibited high selfconfidence level after the implementation of $\mathrm{CNI}$ especially in delivery of patient care. The students' ability to listen, to recognize, to identify health issues even from non-verbal cues on patients' problem was one of the highest achievements after the implementation of the CNI. In conclusion, a structured program on how to guide students learning in the clinical placement will improve the confidence level especially for the beginners and no matter how weak the guideline is, it's really worth it.
\end{abstract}

Keywords: Clinical nursing; Clinical nursing initiatives; Nursing; Nursing student; Self worth

\section{Introduction}

Clinical learning is a fundamental element in nursing curricula from sourcing of appropriate experiences for students to national board registration requirements and workforce requirements. The clinical education component for undergraduate nursing students and the diploma nursing students had over the last few years received much attention $[1,2]$. Various approaches to clinical teaching models have been developed for nursing students worldwide [3-6]. Hence, it is evident that the clinical nursing environment not only plays an important role in the development of the students' competency but also with their confidence, organizational skills, and practical preparedness.

Clinical placement is an integral educational component in the learning process of nursing students. It provides nursing students with a hands-on experience in the real world of nursing, i.e., to practice clinical skills. Students will prepare themselves to practice caring for real patients with various illnesses at the hospital during the clinical placement in the first semester. The process of transferring theory into practice is an integral part in being successful in nursing education [7]. Therefore, in clinical learning requires a variety of clinical settings in order to gain hands-on experience with the purpose of applying the theory into practice. The practical preparations entail more than just developing skills in the laboratory. It involves the ability to provide safe and effective care to other individuals in various clinical settings.
In the early 20th century the model of training for nurses at that time was based on an apprenticeship model whereby nursing students provided service (direct patient care) in exchange for a few educational lectures, room and board and a monthly allowance. However, the effectiveness of clinical teaching learning pertaining to nursing practice among undergraduate students had long been the focus of debate with various researchers. It was discovered that students had been craving for the opportunity to apply the skills and knowledge that had been presented by clinical teachers and that the clinical environment had been a source of inspiration for the nursing practice of undergraduate students.

The combination of theoretical and practical skills in real-life situations had been found greatly influenced in students' learning of acquiring the core skills of which is the central to the development of skill acquisition. It is a compulsory measure that the nurse educators play a major role in promoting and overseeing the improvisation of positive clinical teaching activities. The clinical instructor or teacher or preceptor whatever we called them, was identified as a pivotal personnel for the development and sustainability of the teachingenvironment, establishing a strong rapport between students and members of the ward staff.

For students especially the first year of their clinical experiences were identified as one of the most challenging experience as novice students. As beginner in the nursing field, they usually have fears with the clinical environment. The first exposure to caring for life is overbearing for them. The purpose of this study was to prepare the first year nursing students the confidence level, competence and safe 
patient care delivery through a structured clinical program called Clinical Nursing Initiatives (CNI).

\section{Background of the Study}

This study had been conducted in one of the private hospitals in Kuala Lumpur city, Malaysia. This hospital receives First Year Semester Diploma Nursing Students from Semesters 1, 2 and 3 every year. These students are chosen from two institutions under the same organization of KPJ University College which is located in Nilai and KPJ International College in Johor Bahru. These students inherit the same clinical objectives and learning outcomes with regards to the clinical placements. In both institutions, students will prepare for 12 weeks of theory on the fundamentals of nursing, the anatomy of the human body and skills in providing basic nursing care for patients prior to their clinical placements.

In the clinical area of each hospital, a minimum of 2 Nurse Instructors (NI) will be allocated for student supervision. The workload of the nurse instructors is shared equally in the supervision of student nurses in a clinical placement and they are kept up-to-date on the roles and duties in the absence of another.

In the normal practice for clinical placement for First Year, students will be placed in both the medical and surgical wards. The selection of clinical exposure will be determined by the nurse instructors from the respective wards and the learning requirement is understandably in line with the prior theory learnt in the classroom. Students will be introduced to the hospital setting, policies and procedures including the clinical objectives in one dedicated day as an orientation programme before they could really start the placement activities. During the placement, students are required to relate the theory component into practice including patient care delivery system, history taking from their illnesses, required care and health awareness.

Most students find challenges in adapting to the clinical area for the first time with regards to their lack of fundamental knowledge of the human anatomy, with zero experience in primary patient care. The challenges start on the first day of stepping into the reality of transforming theory into practice, and this has become the primary concern for both students and teachers leading the nursing students in having the lack of self-confidence [8]. This ultimately will take up much time to ease the anxiety and limit the learning opportunities.

The ever changing and unpredictable situations in the clinical areas often resulted in student's inability to 'fit in' the new environment, particularly at the beginning of the clinical placement. The feelings of anxiety and fear of the unfamiliarity and not knowing what to do were often the phenomena reported. Sometimes the unwillingness of staff to teach and to assist those first-year nursing students with their high expectation was often imposed on the new students in the First Year of the course they go through.

\section{Methods and Methodology}

This is a Quasi Experimental One Group pre-test and post-test design that will demonstrate the causality between an intervention and an outcome of a study.

\section{What is CNI?}

With regards to this study, an initiative called "Clinical Nursing Initiatives" or CNI was developed based on the first year nursing student's needs in the clinical area. A blended approach from the previous clinical teaching strategies, hospital policies and some specific needs requested by students were added into new development initiatives and made customized to those students who came to this particular hospital for clinical placement for the first time. It is important as for the first timers, as Kelly [9] gives his views on this matter to all teachers, how do we really know what students are actually learning when they are in the process of learning something new for the first time?. As lecturers, we are not mind readers; we need to check in with our students to find out what they are learning and what they don't understand fully. Based on that point of views, an initiative was developed for first-year students' supervision guidelines.

Elements such as student's anxiety level, self-satisfaction level with the clinical learning experience, self-confidence on level and selfconfidence in delivering patient care after the implementation of the $\mathrm{CNI}$ are the main concern of elements of preparing the First Year nursing students in clinical placement.

Instrument that measures the outcomes of the implementation of the CNI was based on validated instruments adapted and adopted from Kroenke et al. [10], White [11] and Jeffries et al. [12].

Table 1 shows a brief development of the Clinical Nursing Initiatives with modification of previous clinical teaching approaches and integration of the hospital policies.

The total number of students from the Diploma of Nursing Programme that will be posted to KPJ Tawakkal Hospital was approximately 200 students from various semesters in each year. They were from KPJ International College, Johor Baharu and KPJ Healthcare University College, Nilai. However, for the purpose of this study, the samples had been selected from 30 first year students of KPJ International College, Johor Baharu and KPJ Healthcare University College, Nilai.

\section{Sampling and techniques}

Sample size by calculation:

$-(1.96)(1.96)(0.50) *(1-0.50) /(0.17)(0.17)$
$=1.9208 \times 0.50 / 0.0289$
$=0.9604 / 0.0289$
$=3.2333$

\section{Inclusion criteria}

The Inclusive criteria had shown that the participants who had attended the Clinical placement at KPJ Tawakkal specialist hospital comprised of first year Semesters 1,2 and 3 Diploma in nursing students.

\section{Exclusion criteria}

The exclusive criteria were the others years and semester of nursing student came to clinical placement in KPJ Tawakkal specialist hospital (Table 2).

For the First Year Diploma of Nursing it comprises students from the three semesters, i.e., Semesters 1, 2 and 3. The same students were the main respondents throughout the study. 
Citation: Yen WP, Abidin NRZ, Mansor NH, Annamma K, Hassan H (2017) Structured Clinical Teaching Initiatives: A Preparation for First Year Nursing Students as First Timer in the Clinical Placement. J Nurs Care 6: 435. doi:10.4172/2167-1168.1000435

\begin{tabular}{|c|c|}
\hline $\begin{array}{l}\text { Element of Preparing the First Year } \\
\text { Students in Clinical Placement }\end{array}$ & Activities \\
\hline \multirow{5}{*}{$\begin{array}{l}\text { Original Clinical Teaching approaches } \\
\text { (Before CNI) }\end{array}$} & One day orientation \\
\hline & Briefing on Nursing and patient Care Plan \\
\hline & Bedside teaching based on opportunities \\
\hline & Supervision towards end of placement \\
\hline & Clinical evaluation end of posting \\
\hline \multirow{17}{*}{ Existing Hospital Policies and Initiatives } & KPJ Ways \\
\hline & 10 basic courtesy (Soft skill in nursing - Standard People Practice, the KPJ Way) \\
\hline & Structured Nursing Round \\
\hline & Patient Safety (6) Goals \\
\hline & Infection Control educational package on: \\
\hline & Hand Hygiene \\
\hline & Waste Management \\
\hline & Disinfectant/Sterilization, \\
\hline & Housekeeping/Spillage \\
\hline & Needle Stick Injury \\
\hline & Isolation Nursing. \\
\hline & Emergency procedures and responsibilities \\
\hline & CPR \\
\hline & Code Blue \\
\hline & Disaster Codes -Yellow, Red and Pink \\
\hline & Health Screening - CSR \\
\hline & (Nursing Students were involve with the hospital initiative - medical screening assisting the trained nurse) \\
\hline \multirow{7}{*}{ Modification of Clinical Teaching } & 14 days Orientation Program \\
\hline & Structured activities from Day 1 till 14 th day \\
\hline & Structured bedside teaching \\
\hline & Ongoing Evaluation \\
\hline & Students feedback \\
\hline & $Q$ and $A$ \\
\hline & Ensuring learning has taken place strategies \\
\hline
\end{tabular}

Table 1: The development of 3 initiatives to form a clinical nursing initiatives (CNI).

\section{Data collection}

The implementation of CNI starts from Semester 1. The process can be observed from the Tables $3 a$ and $3 b$ and the focus of teaching and supervising was emphasized in the structured program activities. The implementation of the CNI will take place throughout the number of weeks of each semester. As for semester 2 and 3, the teaching was only emphasised for one day. This is because the main focus sample of this study were year 1 semester 1students. This group of students were very new to clinical placement with low self-confidence. As a beginner in the nursing field, students usually harbour fears related to the clinical environment and first exposure to caring for life. It is imperative for first year nursing students to gain confidence in a clinical learning setting. Clinical experiences are identified as one of the most challenging subjects in the program for novice student nurses. Clinical 
Citation: Yen WP, Abidin NRZ, Mansor NH, Annamma K, Hassan H (2017) Structured Clinical Teaching Initiatives: A Preparation for First Year Nursing Students as First Timer in the Clinical Placement. J Nurs Care 6: 435. doi:10.4172/2167-1168.1000435

Page 4 of 10

Instructors employed in the hospital settings have a vital role in influencing nursing student's clinical experiences.

The data was collected for the 3 consecutive semesters for comparison purposes. Collection of data for Semester 1 was done at the end of the posting. Students evaluated the learning experience based on the instrument from Kroenke et al. [10], White [11] and
Jeffries et al. [12]. The outcome variables measured were students' Selfsatisfaction with the clinical learning experience, Self-confidence with the clinical learning experience and Self-confidence of delivering patient care after the implementation of CNI. The same questionnaire was read administered during Semesters 2 and 3.

\begin{tabular}{|l|l|l|}
\hline $\begin{array}{l}\text { Area of concerns in the Preparation of First Year Nursing } \\
\text { students }\end{array}$ & Authors & Outcomes \\
\hline General Anxiety Level & Kroenke et al. [10] & The anxiety level related to the pre-clinical placement. \\
\hline Self-Satisfaction with the clinical learning experience & Jeffries et al. [12] & $\begin{array}{l}\text { Self-satisfaction level in clinical teaching and learning before and after } \\
\text { implementation of CNI }\end{array}$ \\
\hline Self-Confidence with the clinical learning experience & Jeffries et al. [12] & $\begin{array}{l}\text { Self-confidence level in clinical exposures before and after implementation of } \\
\text { CNI }\end{array}$ \\
\hline $\begin{array}{l}\text { Self-Confidence in delivering patient care before and after the } \\
\text { CNI }\end{array}$ & White [11] & Self-confidence of delivering patient care pre and post implementation of CNI \\
\hline
\end{tabular}

Table 2: Instruments that measure components on the implementation of CNI.

\begin{tabular}{|c|c|c|c|c|c|c|c|}
\hline Day & Day 1 & Day 2 & Day 3 & Day 4 & Day 5 & Day 6 & Day 7 \\
\hline & Introduction & $\begin{array}{l}\text { Feedback session } \\
\text { of Day } 1 \mathrm{st}\end{array}$ & $\begin{array}{l}\text { Feedback session } \\
\text { of Day 2nd }\end{array}$ & $\begin{array}{l}\text { Feedback session } \\
\text { of Day 3rd }\end{array}$ & $\begin{array}{l}\text { Feedback session } \\
\text { of Day 4th }\end{array}$ & $\begin{array}{l}\text { Feedback session } \\
\text { of Day 5th }\end{array}$ & $\begin{array}{l}\text { Feedback } \\
\text { session of Day } \\
\text { 6th }\end{array}$ \\
\hline $\begin{array}{l}\text { 8:30 } \\
\text { AM } \\
\text { Tea } \\
\text { Break } \\
\text { 11:00 } \\
\text { AM-12 } \\
\text { Noon }\end{array}$ & $\begin{array}{l}\text { Pre-Test } \\
\text { Welcoming session } \\
\text { Ice Breaking } \\
\text { Introduction on CNI, } \\
\text { KPJ TSH Hospital } \\
\text { and Physical Layout }\end{array}$ & $\begin{array}{l}\text { Clinical Objectives } \\
\text { Requirements for } \\
\text { Year } 1 \text { Semester } 1 . \\
\text { Contact } \mathrm{H} \\
\text { Cross Book } \\
\text { Clinical Placement } \\
\text { activities }\end{array}$ & $\begin{array}{l}\text { Clinical Teaching } \\
\text { learning } \\
\text { Daily tutorials } \\
\begin{array}{l}\text { Feedback patient } \\
\text { care. }\end{array}\end{array}$ & $\begin{array}{l}\text { Hospital Rules and } \\
\text { regulations, do's and } \\
\text { don't } \\
\text { Rostering and } \\
\text { Request mechanism. }\end{array}$ & $\begin{array}{l}\text { Interpersonal Soft } \\
\text { Skill -The KPJ Way } \\
\text { (Ten basic } \\
\text { courtesies) } \\
\text { EPEEP- Standard } \\
\text { Nursing rounds }\end{array}$ & $\begin{array}{l}\text { KPJ Patient safety } \\
\text { Goal. (6 elements) } \\
\text { Audit requirement } \\
\text { MSQH, IMS } \\
\text { accredited Hospital } \\
\text { Abbreviations and } \\
\text { reinforcement of } \\
\text { knowledge on } \\
\text { common diseases/ } \\
\text { conditions }\end{array}$ & $\begin{array}{l}\text { Infection Control } \\
\text { - Hand Hygiene/ } \\
\text { PPE, } \\
\text { Waste } \\
\text { Management, } \\
\text { Disinfectant and } \\
\text { Sterilization, } \\
\text { Housekeeping/ } \\
\text { Spillage } \\
\text { Management) } \\
\text { - Needle Prick } \\
\text { - Isolation } \\
\text { Nursing. }\end{array}$ \\
\hline & Lunch & Lunch & Lunch & Lunch & Lunch & Lunch & Lunch \\
\hline $\begin{array}{l}2 \mathrm{PM} \text { to } \\
5 \mathrm{PM}\end{array}$ & $\begin{array}{l}14 \mathrm{ADL} \\
\text { Bedside teaching } \\
\text { On Breathing } \\
\text { Nursing Care Plan } \\
\text { Process } \\
\text {-Assessment } \\
\text {-Diagnosing } \\
\text {-Planning } \\
\text {-Implementation } \\
\text {-Evaluation } \\
\text {-Demonstration }\end{array}$ & $\begin{array}{l}\text { Bedside teaching on } \\
\text { nutrition and } \\
\text { hydration } \\
\text { Nursing Care Plan } \\
\text { Process } \\
\text {-Assessment } \\
\text {-Diagnosing } \\
\text {-Planning } \\
\text {-Implementation } \\
\text {-Evaluation } \\
\text {-Demonstration }\end{array}$ & $\begin{array}{l}\text { Bedside teaching on } \\
\text { eliminate body waste } \\
\text { Nursing Care Plan } \\
\text { Process } \\
\text {-Assessment } \\
\text {-Diagnosing } \\
\text {-Planning } \\
\text {-Implementation } \\
\text {-Evaluation } \\
\text {-Demonstration }\end{array}$ & $\begin{array}{l}\text { Bedside teaching on } \\
\text { ambulating and } \\
\text { maintaining } \\
\text { desirable positions } \\
\text { Nursing Care Plan } \\
\text { Process } \\
\text {-Assessment } \\
\text {-Diagnosing } \\
\text {-Planning } \\
\text {-Implementation } \\
\text {-Evaluation } \\
\text {-Demonstration }\end{array}$ & $\begin{array}{l}\text { Bedside teaching on } \\
\text { sleeping and resting } \\
\text { Nursing Care Plan } \\
\text { Process } \\
\text {-Assessment } \\
\text {-Diagnosing } \\
\text {-Planning } \\
\text {-Implementation } \\
\text {-Evaluation } \\
\text {-Demonstration }\end{array}$ & $\begin{array}{l}\text { Bedside teaching on } \\
\text { clothing } \\
\text { Nursing Care Plan } \\
\text { Process } \\
\text {-Assessment } \\
\text {-Diagnosing } \\
\text {-Planning } \\
\text {-Implementation } \\
\text {-Evaluation } \\
\text {-Demonstration }\end{array}$ & $\begin{array}{l}\text { Bedside } \\
\text { teaching On } \\
\text { body } \\
\text { temperature } \\
\text { clothing and } \\
\text { changing the } \\
\text { environment } \\
\text { Nursing Care } \\
\text { Plan Process } \\
\text {-Assessment } \\
\text {-Diagnosing } \\
\text {-Planning } \\
\text {-Implementation } \\
\text {-Evaluation } \\
\text {-Demonstration }\end{array}$ \\
\hline & Day 8 & Day 9 & Day 10 & Day 11 & Day 12 & Day 13 & Day 14 \\
\hline
\end{tabular}


Citation: Yen WP, Abidin NRZ, Mansor NH, Annamma K, Hassan H (2017) Structured Clinical Teaching Initiatives: A Preparation for First Year Nursing Students as First Timer in the Clinical Placement. J Nurs Care 6: 435. doi:10.4172/2167-1168.1000435

Page 5 of 10

\begin{tabular}{|c|c|c|c|c|c|c|c|}
\hline $\begin{array}{l}8: 30 \\
\text { AM } \\
\text { Tea } \\
\text { Break } \\
\text { 11:00 } \\
\text { AM-12 } \\
\text { Noon }\end{array}$ & $\begin{array}{l}\text { Feedback session of } \\
\text { Day 7th } \\
\text { Emergency Nursing } \\
\text { Procedures and } \\
\text { Responsibility } \\
\text { Hospital Activities } \\
\text {-Health Screening, } \\
\text { World Health Day }\end{array}$ & $\begin{array}{l}\text { Feedback session } \\
\text { of Day 8th } \\
5 \text { th vital signs } \\
\text {-Practice } \\
\text {-Demonstration and } \\
\text { Return } \\
\text { demonstration } \\
\text { - Recording }\end{array}$ & $\begin{array}{l}\text { Feedback session of } \\
\text { Day 9th } \\
\text { Hospital Equipment } \\
\text { and clinical facilities }\end{array}$ & $\begin{array}{l}\text { Feedback session of } \\
\text { Day 10th } \\
\text { Nursing assessment } \\
\text { based on } \\
\text { Physical } \\
\text { Examination, } \\
\text {-Observation } \\
\text {-Interview } \\
\text {-Palpation } \\
\text {-Demonstration } \\
\text {-Return } \\
\text { demonstration }\end{array}$ & $\begin{array}{l}\text { Feedback session of } \\
\text { Day 11th } \\
\text { Enhancement of } \\
\text { Professionalism } \\
\text {-Grooming } \\
\text {-Nursing Ethics }\end{array}$ & $\begin{array}{l}\text { Feedback session of } \\
\text { Day } 12 \text { th } \\
\text { Shift duty and } \\
\text { nursing responsibility } \\
\text { Senior Living Care } \\
\text { Introduction for } \\
\text { Clinical Placement }\end{array}$ & $\begin{array}{l}\text { Feedback } \\
\text { session of Day } \\
\text { 13th } \\
\text { Evaluation } \\
\text { Q and A } \\
\text {-Verbal } \\
\text { feedback } \\
\text {-Sharing and } \\
\text { expressing } \\
\text { ideas }\end{array}$ \\
\hline $\begin{array}{l}1 \text { PM-2 } \\
\text { PM }\end{array}$ & Lunch & Lunch & & Lunch & Lunch & Lunch & Lunch \\
\hline $\begin{array}{l}2 \mathrm{PM} \text { to } \\
5 \mathrm{PM}\end{array}$ & 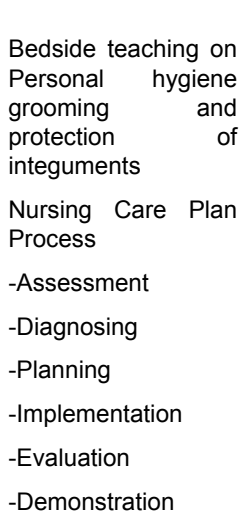 & $\begin{array}{l}\text { Bedside teaching on } \\
\text { Safety at work } \\
\text { Physical injury } \\
\text { Emotional } \\
\text { Psychosocial safety } \\
\text { Nursing Care Plan } \\
\text { Process } \\
\text {-Assessment } \\
\text {-Diagnosing } \\
\text {-Planning } \\
\text {-Implementation } \\
\text {-Evaluation } \\
\text {-Demonstration }\end{array}$ & $\begin{array}{l}\text { Bedside teaching on } \\
\text { Safety at work } \\
\text { Physical injury } \\
\text { Emotional } \\
\text { Psychosocial safety } \\
\text { Nursing Care Plan } \\
\text { Process } \\
\text {-Assessment } \\
\text {-Diagnosing } \\
\text {-Planning } \\
\text {-Implementation } \\
\text {-Evaluation } \\
\text {-Demonstration }\end{array}$ & $\begin{array}{l}\text { Bedside teaching on } \\
\text { spiritual practice and } \\
\text { support. } \\
\text { Nursing Care Plan } \\
\text { Process } \\
\text {-Assessment } \\
\text {-Diagnosing } \\
\text {-Planning } \\
\text {-Implementation } \\
\text {-Evaluation } \\
\text {-Demonstration }\end{array}$ & $\begin{array}{l}\text { Bedside teaching on } \\
\text { Self-care } \\
\text { Nursing Care Plan } \\
\text { Process } \\
\text {-Assessment } \\
\text {-Diagnosing } \\
\text {-Planning } \\
\text {-Implementation } \\
\text {-Evaluation } \\
\text {-Demonstration }\end{array}$ & $\begin{array}{l}\text { Bedside teaching on } \\
\text { lifelong learning } \\
\text { Nursing Care Plan } \\
\text { Process } \\
\text {-Assessment } \\
\text {-Diagnosing } \\
\text {-Planning } \\
\text {-Implementation } \\
\text {-Evaluation } \\
\text {-Demonstration }\end{array}$ & \\
\hline
\end{tabular}

Table 3: Clinical placement structured orientation program (14days) for first year semester one diploma of nursing.

\section{Data analysis}

The above result shows that there had been a strong significance in the overall anxiety levels throughout Semesters 1, 2 and 3. In Semester 1 , the students had scored $n=19(63.3 \%)$ at a moderate level of anxiety. As the learning had progressed to Semesters 2 and 3, the anxiety level had decreased (Tables $4 \mathrm{a}$ and $4 \mathrm{~b}$ ).

Table 5a had shown the Post-test for the scoring level of Selfsatisfaction on the learning experience through CNI for Semester1, 2 and 3. Respondents had displayed a great advancement in Semester 1. However, there had been a slight decrease in the level of selfsatisfaction of the learning experience in Semesters 2 and 3, may due to different individual perception on self- satisfaction level.

\begin{tabular}{|l|l|l|l|}
\hline Anxiety Level & Semester 1 & Semester 2 & Semester 3 \\
\hline Low anxiety & $10(33.3 \%)$ & $21(70.0 \%)$ & $24(80.0 \%)$ \\
\hline Moderate anxiety & $19(63.3 \%)$ & $8(26.7 \%)$ & $4(13.3 \%)$ \\
\hline High anxiety & $1(3.3 \%)$ & $1(3.3 \%)$ & $2(6.7 \%)$ \\
\hline
\end{tabular}

Table 4(a): The levels of anxiety for Semesters 1,2 and 3 before Implementation of CNI.

\begin{tabular}{|c|c|c|c|c|c|c|c|}
\hline & \multirow[t]{2}{*}{ (I) Participant ID } & \multirow[t]{2}{*}{ (J) Participant ID } & \multirow[t]{2}{*}{$\begin{array}{l}\text { Mean Difference (I- } \\
\text { J) }\end{array}$} & \multirow[t]{2}{*}{ Std. Error } & \multirow[t]{2}{*}{ Sig. } & \multicolumn{2}{|c|}{ 95\% Confidence Interval } \\
\hline & & & & & & Lower Bound & Upper Bound \\
\hline \multirow[t]{5}{*}{ Bonferroni } & Semester 1 & Semester 2 & 0.30952 & 0.14996 & 0.126 & -0.0566 & 0.6756 \\
\hline & & Semester 3 & $0.72381^{*}$ & 0.14996 & 0 & 0.3577 & 1.0899 \\
\hline & Semester 2 & Semester 1 & -0.30952 & 0.14996 & 0.126 & -0.6756 & 0.0566 \\
\hline & & Semester 3 & $0.41429^{*}$ & 0.14996 & 0.021 & 0.0482 & 0.7804 \\
\hline & Semester 3 & Semester 1 & $-0.72381^{*}$ & 0.14996 & 0 & -1.0899 & -0.3577 \\
\hline
\end{tabular}


Citation: Yen WP, Abidin NRZ, Mansor NH, Annamma K, Hassan H (2017) Structured Clinical Teaching Initiatives: A Preparation for First Year Nursing Students as First Timer in the Clinical Placement. J Nurs Care 6: 435. doi:10.4172/2167-1168.1000435

Page 6 of 10

\begin{tabular}{|l|l|l|l|l|l|l|}
\hline & Semester 2 & $-0.41429^{*}$ & 0.14996 & 0.021 & -0.7804 & -0.0482 \\
\hline * The mean difference is significant at the 0.05 level \\
\hline
\end{tabular}

Table 4(b): Multiple comparisons on the levels of anxiety for Semesters 1,2 and 3.

Table $5 \mathrm{~b}$ had shown the positive impact and significance result as the level had indicated 0.000 whereby, the nursing students had been satisfied with the application of CNI.

Table $5 \mathrm{c}$ had exhibited the overall level in the development of selfconfidence after the implementation of CNI. Students had scored a high ranking for all the three semesters.

The Bonferroni test had shown that there was no significant changes on self-confidence level between Semesters 1, 2 and 3, because in all the three semesters, students had shown the keenness on the implementation of CNI to assist them in their clinical knowledge

\begin{tabular}{|l|l|l|l|}
\hline $\begin{array}{l}\text { Self-Satisfaction of the } \\
\text { Learning experience } \\
\text { through CNI }\end{array}$ & Semester 1 & Semester 2 & Semester 3 \\
\hline Low & 0 & 0 & 0 \\
\hline Moderate & $2(6.7 \%)$ & $10(33.3 \%)$ & $10(33.3 \%)$ \\
\hline High & $28(93.3 \%)$ & $20(66.7 \%)$ & $20(66.7 \%)$ \\
\hline
\end{tabular}

Table 5(a): Self-Satisfaction with the implementation of CNI between semesters.

(Table 5d)

\begin{tabular}{|c|c|c|c|c|c|c|c|}
\hline & \multirow[t]{2}{*}{ (I) Participant ID } & \multirow[t]{2}{*}{ (J) Participant ID } & \multirow[t]{2}{*}{$\begin{array}{l}\text { Mean Difference (I- } \\
\text { J) }\end{array}$} & \multirow[t]{2}{*}{ Std. Error } & \multirow[t]{2}{*}{ Sig. } & \multicolumn{2}{|c|}{ 95\% Confidence Interval } \\
\hline & & & & & & Lower Bound & Upper Bound \\
\hline \multirow[t]{6}{*}{ Bonferroni } & 1 & 2 & $0.48667^{*}$ & 0.13802 & 0.002 & 0.1497 & 0.8236 \\
\hline & & 3 & $0.55333^{*}$ & 0.13802 & 0 & 0.2164 & 0.8903 \\
\hline & 2 & 1 & $-0.48667^{*}$ & 0.13802 & 0.002 & -0.8236 & -0.1497 \\
\hline & & 3 & 0.06667 & 0.13802 & 1 & -0.2703 & 0.4036 \\
\hline & 3 & 1 & $-0.55333^{*}$ & 0.13802 & 0 & -0.8903 & -0.2164 \\
\hline & & 2 & -0.06667 & 0.13802 & 1 & -0.4036 & 0.2703 \\
\hline
\end{tabular}

Table 5(b): Multiple Comparisons on self-satisfaction in the learning experience through CNI between Semesters 1, 2 and 3.

\begin{tabular}{|l|l|l|l|}
\hline $\begin{array}{l}\text { Self-Confidence } \\
\text { development after } \\
\text { the CNI }\end{array}$ & Semester 1 & Semester2 & Semester 3 \\
\hline Low & 0 & 0 & 0 \\
\hline Moderate & $3(10 \%)$ & $5(16.7 \%)$ & $5(16.7 \%)$ \\
\hline
\end{tabular}

\begin{tabular}{|l|l|l|l|}
\hline High & $27(90 \%)$ & $25(83.3 \%)$ & $25(83.3 \%)$ \\
\hline
\end{tabular}

Table 5(c): Self-confidence with the implementation of CNI between semesters.

\begin{tabular}{|c|c|c|c|c|c|c|c|}
\hline & (I) Participant ID & (J) Participant ID & $\begin{array}{l}\text { Mean Difference (I- } \\
\text { J) }\end{array}$ & Std. Error & Sig. & \multicolumn{2}{|c|}{$95 \%$ Confidence Interval } \\
\hline & & & & & & Lower Bound & Upper Bound \\
\hline \multirow[t]{5}{*}{ Bonferroni } & 1 & 2 & 0.2125 & 0.12742 & 0.297 & -0.0986 & 0.5236 \\
\hline & & 3 & 0.17083 & 0.12742 & 0.551 & -0.1402 & 0.4819 \\
\hline & 2 & 1 & -0.2125 & 0.12742 & 0.297 & -0.5236 & 0.0986 \\
\hline & & 3 & -0.04167 & 0.12742 & 1 & -0.3527 & 0.2694 \\
\hline & 3 & 1 & -0.17083 & 0.12742 & 0.551 & -0.4819 & 0.1402 \\
\hline
\end{tabular}


Citation: Yen WP, Abidin NRZ, Mansor NH, Annamma K, Hassan H (2017) Structured Clinical Teaching Initiatives: A Preparation for First Year Nursing Students as First Timer in the Clinical Placement. J Nurs Care 6: 435. doi:10.4172/2167-1168.1000435

Page 7 of 10

\begin{tabular}{|l|l|l|l|l|l|l|l|}
\hline & & 2 & 0.04167 & 0.12742 & 1 & -0.2694 & 0.3527 \\
\hline
\end{tabular}

Table 5(d): Multiple comparisons on the development of self-confidence after the implementation of CNI between Semesters 1, 2 and 3.

Tables $6 \mathrm{a}$ and $6 \mathrm{~b}$ had shown the level of confidence towards patient care in Semesters 1, 2 and 3. Prior to the implementation of CNI, the confidence level in the majority of the students had been moderate. Overall, there had been a minimal difference in the confidence level between Semester 1, 2 and 3 before the introduction of CNI.

Tables $6 \mathrm{c}$ and $6 \mathrm{~d}$ had illustrated the overall level of self-confidence towards patient care post- CNI, whereby students had scored a high ranking in all three semesters. The Bonferroni test had not shown a significant value between semesters due to the high scores displayed by students in all three semesters post-CNI implementation.

\begin{tabular}{|l|l|l|l|}
\hline $\begin{array}{l}\text { Level of self-confidence } \\
\text { toward patient care } \\
\text { before CNI }\end{array}$ & Semester 1 & Semester 2 & Semester 3 \\
\hline Low & $3(10.0 \%)$ & $4(13.3 \%)$ & $4(13.3 \%)$ \\
\hline Moderate & $19(63.3 \%)$ & $17(56.7 \%)$ & $17(56.7 \%)$ \\
\hline High & $8(26.7 \%)$ & $9(30.0 \%)$ & $9(30.0 \%)$ \\
\hline
\end{tabular}

Table 6(a): Pre-test: Level of self-confidence towards patient care for semesters 1,2 and 3.

\begin{tabular}{|c|c|c|c|c|c|c|c|}
\hline & \multirow[t]{2}{*}{ (I) Participant ID } & \multirow[t]{2}{*}{ (J) Participant ID } & \multirow[t]{2}{*}{$\begin{array}{l}\text { Mean Difference } \\
(\mathrm{I}-\mathrm{J})\end{array}$} & \multirow[t]{2}{*}{ Std. Error } & \multirow[t]{2}{*}{ Sig. } & \multicolumn{2}{|c|}{ 95\% Confidence Interval } \\
\hline & & & & & & $\begin{array}{l}\text { Lower } \\
\text { Bound }\end{array}$ & $\begin{array}{l}\text { Upper } \\
\text { Bound }\end{array}$ \\
\hline \multirow[t]{6}{*}{ Bonferroni } & 1 & 2 & -0.01376 & 0.17691 & 1 & -0.4456 & 0.4181 \\
\hline & & 3 & -0.08274 & 0.17691 & 1 & -0.5146 & 0.3491 \\
\hline & 2 & 1 & 0.01376 & 0.17691 & 1 & -0.4181 & 0.4456 \\
\hline & & 3 & -0.06898 & 0.17691 & 1 & -0.5009 & 0.3629 \\
\hline & 3 & 1 & 0.08274 & 0.17691 & 1 & -0.3491 & 0.5146 \\
\hline & & 2 & 0.06898 & 0.17691 & 1 & -0.3629 & 0.5009 \\
\hline
\end{tabular}

Table 6(b): The pre-test of self-confidence level towards patient care on multiple comparisons for semesters 1, 2 and 3.

\begin{tabular}{|l|l|l|l|}
\hline $\begin{array}{l}\text { Self-Confidence } \\
\text { towards patient care }\end{array}$ & Semester 1 & Semester2 & Semester 3 \\
\hline Low & 0 & 0 & 0 \\
\hline Moderate & $7(23.3 \%)$ & $8(26.7 \%)$ & $1(3.3 \%)$ \\
\hline
\end{tabular}

\begin{tabular}{|l|l|l|l|}
\hline High & $23(76.7 \%)$ & $22(73.3 \%)$ & $29(96.7 \%)$ \\
\hline
\end{tabular}

Table 6(c): Post-test of CNI in the self-confidence towards patient care.

\begin{tabular}{|c|c|c|c|c|c|c|c|}
\hline & $\begin{array}{l}\text { Among First Year } \\
\text { Semesters 1, } 2 \text { and } 3 . \\
\text { I) Participant ID }\end{array}$ & (J) Participant ID & $\begin{array}{l}\text { Mean Difference } \\
(I-J)\end{array}$ & Std. Error & Sig. & \multicolumn{2}{|c|}{ 95\% Confidence Interval } \\
\hline & & & & & & Lower Bound & Upper Bound \\
\hline \multirow[t]{6}{*}{ Bonferroni } & 1 & 2 & -0.03704 & 0.13692 & 1 & -0.3713 & 0.2972 \\
\hline & & 3 & $-.40833^{*}$ & 0.13692 & 0.011 & -0.7426 & -0.0741 \\
\hline & 2 & 1 & 0.03704 & 0.13692 & 1 & -0.2972 & 0.3713 \\
\hline & & 3 & $-.37130^{*}$ & 0.13692 & 0.024 & -0.7055 & -0.0371 \\
\hline & 3 & 1 & $.40833^{*}$ & 0.13692 & 0.011 & 0.0741 & 0.7426 \\
\hline & & 2 & $.37130^{*}$ & 0.13692 & 0.024 & 0.0371 & 0.7055 \\
\hline
\end{tabular}

Table 6(d): The Multiple Comparisons on the self-confidence towards patient care. 


\section{Discussion}

Among the overall four outcome variables that had been measured, the General anxiety level showed a decrease as the semester progressed. Students' self-satisfaction in clinical areas and learning through CNI, students showed high score on post implementation of the CNI which means, they had strongly supported this initiative. For the development of self-confidence after the implementation of CNI, a student also showed a high score, which means the CNI has somehow had an impact on their confidence level. Lastly for the self-confidence in providing patient care, students also showed positive impact at the post implementation of CNI.

In Semester 1, students displayed moderate anxiety whereby the feeling of anxiousness before the first clinical placement Lisa and Suzy [13], had commented that the nursing students had experienced much more anxiousness than the students in other major professions. She believed that anxiety is directly associated with a lack of understanding of knowledge, application of knowledge and lack of exposure.

Almost all nursing students had the feeling of anxiousness in the initial clinical placement. The worry of providing the wrong information to the patient had been one of the main issues However, the feeling of anxiety occurs to everyone who is new to unfamiliar places with feeling worry of the unknown, as stated in Weber [14], it is a normal phenomenon to all new comers and this feeling will be diminished once the new comers had received good guidance and support. As this study the pattern had shown that as semester progressed, the anxiety level had dropped and it had clearly shown in the result as $21(70.0 \%)$ in Semester 2.

As for the Self- satisfaction, this element was about the evaluation of students experience in obtaining the clinical experience through implementation of CNI. The content of the CNI had been tailored to their needs of the students previously. Based on that, a clinical teaching program was structured and planned in such a way that multiple teaching and learning approaches such as, bedside teaching, guided knowledge by questions and answer ( $\mathrm{Q}$ and $\mathrm{A})$, demonstration, verbal reflection and clinical feedback. Planning of patient care and interaction with patient as other structured activities that had been allocated in the Orientation Program (OP).
When student where in the Semester 2 clinical posting, they reported high score on the levels of Self-satisfaction with the clinical teaching and learning after the implementation of CNI. Students had been found to be very satisfied with the CNI programme compared to the Semester 1. It was obviously due to the well-structured and coordinated clinical activities that enabled students to enact the real life situations and supported by the clinical instructors involved show more than $20(66.7 \%)$ in all the 3 semesters scored the higher ranking. Such interactive clinical teaching strategies had been agreed by few researchers [15-17]. They emphasized that students level of satisfaction will be high when student were treated with respect, personalized, student involvement, task orientation, innovation, and individualization.

With regards to the Self-confidence in learning, after the implementation of CNI students also had shown a high score in the three semesters. Overall, students exhibited a high self-confidence level in learning, after the implementation of CNI. Students had strongly agreed with the knowledge and skills that had been transferred in the CNI programme.

On Self-satisfaction and Self-confidence after the implementation of CNI, we could conclude that in Semesters 2 and 3 students had ranked highest in self-confidence $(83.3 \%)$. For both Semesters 2 and 3, the feedback had not been done strictly unlike in Semester. This is because, researchers were not be able to be with students as much as a semester 1. Most of the time, semester 2 and 3 students were assisted by the ward staff. This is the area of improvement that needs to be reviewed in the next development of the orientation program for the two semesters.

\section{Self-confidence towards patient care pre- and post- implementation of CNI}

The most interesting part of the results was about the selfconfidence of Semester I students in providing patient care after the implementation of CNI. The result had elaborated the ability of students to transfer the theoretical knowledge into practice specifically in patient care. In Table 7, the results had shown a very interesting significance outcome of the structured program implemented. Below are the description extracted from the Tables 7 and 8 .

\begin{tabular}{|l|l|l|}
\hline Outcome measured & $\mathbf{N}=\mathbf{3 0}(\mathbf{1 0 0})$ & Results \\
\hline General Anxiety Level & Pre Test $19(63.3 \%)$ ranked in Semester 1 & $\begin{array}{l}\text { The results had shown a moderate level of anxiety throughout the three } \\
\text { semesters. However, as the semester had progressed, the anxiety level had } \\
\text { reduced. }\end{array}$ \\
\hline $\begin{array}{l}\text { Self-Satisfaction } \\
\text { experience through CNI learning }\end{array}$ & $\begin{array}{l}\text { Post Test More than } 20(66.7 \%) \text { ranked in all } \\
\text { the 3 semesters }\end{array}$ & $\begin{array}{l}\text { Students scored a high ranking self-satisfaction level after the implementation } \\
\text { of CNI. }\end{array}$ \\
\hline $\begin{array}{l}\text { Self-Confidence development } \\
\text { after the implementation of CNI }\end{array}$ & $\begin{array}{l}\text { Post Test More than } 25(83.3 \%) \text { ranked in all } \\
\text { the } 3 \text { semesters }\end{array}$ & $\begin{array}{l}\text { Students scored a high ranking in self-confidence after the implementation of } \\
\text { CNI. }\end{array}$ \\
\hline $\begin{array}{l}\text { Self-Confidence towards patient } \\
\text { care post-CNI }\end{array}$ & $\begin{array}{l}\text { Pre-test: More than } 17(56.7 \%) \text { ranked in 3 } 3 \\
\text { semesters, Post-test: More than 22 (73.3\%) } \\
\text { ranked in 3 semesters. }\end{array}$ & $\begin{array}{l}\text { Students scored moderately during the pre-implementation of CNI. However, } \\
\text { they had reported a high score at post-CNI. }\end{array}$ \\
\hline
\end{tabular}

Table 7: Overall results on the preparation of first year nursing students in clinical placement through implementation of Clinical Nursing Initiative (CNI).

\begin{tabular}{|l|l|l|l|l}
\hline Semester & $\begin{array}{l}\text { Students' highest Score on the ability and self-confidence towards providing patient care after } \\
\text { the implementation of CNI }\end{array}$ & Total no. Respondents/Scores \\
\hline
\end{tabular}




\begin{tabular}{|l|l|l|}
\hline & & $\mathbf{N = 3 0 ~ ( 1 0 0 \% )}$ \\
\hline 1 & $\begin{array}{l}\text { Able to be an active listener in gathering patient's medical information through interview and reading } \\
\text { patient's charts as well as the know-how to plan the nursing care according to patient's illness }\end{array}$ & $\begin{array}{l}\text { High } \\
23(76.7 \%)\end{array}$ \\
\hline 2 & $\begin{array}{l}\text { Able to listen carefully to a patient's health issues and able to recognize the signs and symptoms of } \\
\text { wound healing and recognized the differences in calculation of intravenous fluids solution }\end{array}$ & $\begin{array}{l}\text { High } \\
22(73.3 \%)\end{array}$ \\
\hline 3 & $\begin{array}{l}\text { Perform skill on non-verbal cues on patients with cardiac and respiratory conditions and ability to plan } \\
\text { and also to carry out the specific care to the above conditions. }\end{array}$ & $\begin{array}{l}\text { High } \\
29(96.7 \%)\end{array}$ \\
\hline
\end{tabular}

Table 8: Students great achievement in self-confidence towards providing patient care after the implementation of CNI.

In Semester 1: Students were able to be an active listener in gathering patient's medical information through interview and reading patient's charts as well as the know-how to plan the nursing care according to patient's illness.

In Semester 2: Students were able to listen more carefully to a patient's health issues and able to recognize the signs and symptoms of wound healing and recognized the differences in calculation of intravenous fluids solution

In Semester 3: Perform skill on non-verbal cues on patients with cardiac and respiratory conditions and ability to plan and also to carry out the specific care of patients with cardio vascular and Respiratory specific conditions.

In conclusion, CNI programme has produced students to learn not only delivering patient care at the required standard expected, but CNI also has produced good communication skill among students in the three semester, particularly as good listener. For this study, students were taught to listen carefully to patients' complaints and students gathered the information. Then they learnt to assess patient through the non-verbal cues, before they could summed up the information for planning of the care. This is something unexpected result although we know in our nursing standard on patient care; good communication is one of our main concerns. As everyone knows, improving communication among healthcare professional has a major impact on patients' safety since one of the important causes of medical errors and unintentional harm to patients is ineffective communication Vahid et al. [18].

This study was conducted by a researcher who is also the clinical instructor to nursing all the students from the particular university college. She herself was able to feel the importance of bringing up a program that benefits students, the clinical instructors and even the hospitals and faculty that can provide guidance of good learning environment in clinical areas.

Indeed a registered nurse who are assigned to take charge of nursing students are supposed to take this initiative as they are the ones who determine the competence of the student before being confirmed as a nurse. They know the needs of students in the clinical area and the acceptance of the student as a learner who can contribute to the delivery of quality patient care [19].

\section{Conclusion}

The preparation of a structured program on how to guide student learning will improve the confidence level especially for the first timer coming to the clinical placement, is really worth it. No matter how weak the guideline is, it will still benefit the students as a learning guide to help them learn in a structured manner. If an educator can provide structured teaching for classroom instruction, the same method should also be established in the clinical teaching, and it is even more important that the teaching in the clinical should be structured because it is a place where students transform the classroom knowledge to the actual environments on real patients.

\section{References}

1. Lambert V, Glacken M (2005) Clinical education facilitators: A literature review. J Clin Nurs 10: 664-673.

2. Lindgren B, Athlin E (2010) Nurse lecturers' perceptions of what baccalaureate nursing students could gain from clinical group supervision. Nurse Educ Today 30: 360-364.

3. Liu P, Wang T, Wang Y (2006) Research advances in self-management of chronic disease. Chin J Nurs 4: 132-140.

4. Mannix J, Faga P, Beale B, Jackson D (2006) Towards sustainable models for clinical education in nursing: An on-going conversation. Nurse Educ Pract 6: 3-11.

5. Myrick F, Yonge O, Billay D (2010) Preceptorship and practical wisdom: A process of engaging in authentic nursing practice. Nurse Educ Pract 10: 82-87.

6. Warner, M. (2010) Places for this year's conference sponsored by award winning team. Nurs Crit Care 15: 324-330.

7. Edwards H, Smith S, Courtney M, Finlayson K, Chapman H (2004) The impact of clinical placement location on nursing students' competence and preparedness for practice. Nurse Educ Today 24: 248-255.

8. Bembridge E, Jeong SYS (2008) Student nurse confidence: A reflection NOVA. The University of Newcastle's Digital Repository.

9. Kelly D (2005) Do you know what your students are learning? (And do you care?)

10. Kroenke, Robert LS, Janet BWM, Patrick OM, Bernd Lo (2007) Anxiety disorders in primary care: Prevalence, impairment, comorbidity and detection. Ann Intern Med 146: 317-325.

11. White KA (2011) The development and validation of a tool to measure self-confidence and anxiety in nursing students while making clinical decisions. J Nurs Educ 53: 14-22.

12. Jeffries PR, Boland D, Mc Adams S (2005) The use of simulations to provide experiential learning in nursing education. A programme and review and assessment Committee Grant Proposal.

13. Sparacino L, Diggle BS (2017) Reducing perceived stress through an orientation program for nursing students entering their first nursing course. J Nurs Educ Pract 7: 54

14. Weber (2012) Applying social psychology to personal relationships. In: Applied social psychology: Understanding and addressing social and practical problems, FW Schneider, JA Gruman, LM Coutts (eds.) SAGE Publications, Thousand Oaks, CA. 
Citation: Yen WP, Abidin NRZ, Mansor NH, Annamma K, Hassan H (2017) Structured Clinical Teaching Initiatives: A Preparation for First Year Nursing Students as First Timer in the Clinical Placement. J Nurs Care 6: 435. doi:10.4172/2167-1168.1000435

Page 10 of 10

15. Smyth PAC (2005) The lived experiences of general student nurses on their first clinical placement: A phenomenological study. Nurse Educ Pract 5: 320-327.

16. Régo P, Peterson R, Callaway L, Ward M, O’Brien C et al.(2009) Using a structured clinical coaching program to improve clinical skills training and assessment, as well as teachers and students satisfaction. Med Teacher 31: e586-595.

17. Brown T, Williams B, McKenna L, Palermo C, McCall L, et al. (2011) Practice education learning environments: The mismatch between perceived and preferred expectations of undergraduate health science students. Nurse Educ Today 31: e22-28.

18. Jahromi VK, Tabatabaee SS, Abdar ZE, Rajabi M (2016) Active listening: The key of successful communication in hospital managers. Electron Physician 8: 2123-2128.

19. Nursing and Midwifery Board of Ireland (NMBI) 2015. 